\title{
The Research of Dependency between the Size of the Cadastral Plots and the Measurement Error of Their Areas Using a Handheld GPS Receiver**
}

\section{Introduction}

The twenty-first century has brought many changes associated with technical advances in geodesy. An example of the use of newer generation devices in the work of surveying, are handheld GPSmap62st receivers, which allow the user quick, easy and relatively accurate $(3-5 \mathrm{~m})$ positioning based on existing satellite navigation systems GNSS [9]. They can be used (according to their basic function and purpose) for navigation to a point to find on the ground approximate location of geodetic control points, based on the coordinates of the point acquired from the topographic description [7]. The navigation function is also useful when the surveyor has the difficult task of finding the measurement object in the form of a undeveloped cadastral plot in the agriculture or forestry area, for further surveying on its territory. Cartographic materials in the form of extract from the cadastral map or a part of basic map of little varied terrain sometimes are not sufficient to uniquely identify such a plot, and the number of plots alone is too general information to find it on the ground. Handheld GPS receivers had proved themselves to be viable during an inventory of agricultural land. They allow, in a quick and reasonably accurate way, for measuring the length, perimeter or area of a plot [4], for the purposes of verification of a farmers' applications on the declared crop area. In recent years methods of verification using GPS receivers have been replaced by photogrammetric methods based on a orthophotomap, however, the receiver is useful in other types of surveying with the lowest precision demands and for GIS analyses [7]. The problem of the use of hand-held GPS receivers is shown in the literature concerning this subject, inter alia in $[3,4,7-9]$. On the other hand in the papers [1,2] were presented the analysis of the accuracy of the calculations of the areas of the plots by analytical methods.

\footnotetext{
* University of Agriculture in Krakow, Poland

** University of Life Sciences in Lublin, Faculty of Production Engineering, Department of Engineering, Environmental Development and Surveying, Poland
} 
This article raises a new topic of research on the accuracy of hand-held GPSmap62st receivers in determining the influence of the size of the area to be measured on the results of its measurement. Contribution to undertake the research was information, taken from the instructions for field inspectors, carrying out work for the needs of the Single Area Payment System (at the beginning of the system operation) regarding the need to repeat measurements of area for plots less than 0.5 ha. Plots of more than 0.5 ha could be measured only once without a multiple measurement averaging. Based on that, it can be assumed that the measurement of plots of a larger area is more accurate than the measurement results of the smaller plot. In the literature there is no information about the veracity of this thesis. This work is thus an attempt to answer the question whether the size of the measured area can be a factor deciding on the accuracy of its determination, using a handheld GPSmap62st receiver.

\section{Method of Measurement Work}

\subsection{Optimization of Measurement Conditions}

During the field work the optimal measurement conditions were secured to work with GPS equipment. The measuring base was founded on the ground with the exposed horizon and interference-free reception of satellite signals in the form of the occurrence of field obstacles. The measurement was performed under favorable weather conditions, the air temperature was between $-2^{\circ} \mathrm{C}$ and $0{ }^{\circ} \mathrm{C}$, the sky was partly cloudy, no rain. An important element of the work was to apply the highest possible accuracy, by launching the EGNOS system and the measurement of the area with the receiver operating in this mode. EGNOS System (European Geostationary Navigation Overlay Service) is a European system supporting the users of aviation, marine and terrestrial GPS and GLONASS systems. The tasks of EGNOS are primarily: improving range of GPS system by increasing the number of visible satellites, increasing the accuracy of the determined position, increase of the safety of users, who will be informed about the GPS system errors during the measurement. It should be added that EGNOS is the European equivalent of the American support system WAAS and MSAS system that covers the area around Japan.

\subsection{Selection of Measuring Equipment}

The handheld Garmin satellite receiver - GPSmap62st (Fig. 1) was selected for the study. This device meets user requirements as it is functional, well made, yet simple and intuitive to use.

According to [10] the receiver is resistant, waterproof, equipped with a helical antenna with four coils providing a good signal reception. It is equipped with a 3-axis tilt-compensated compass, which means that indicates the direction of the north, even when the device is not in the horizontal position and does not move. Its advantage is that it has preloaded $100 \mathrm{~K}$ topographic maps, barometric altimeter, 
which precisely defines the measurement height, 2.6 inch color screen readable even in sunny days. The device has a BirdsEye Satellite Imagery service (subscription required). The user of the receiver can wirelessly share waypoints, routes and geocaches with the users of other compatible Garmin devices.

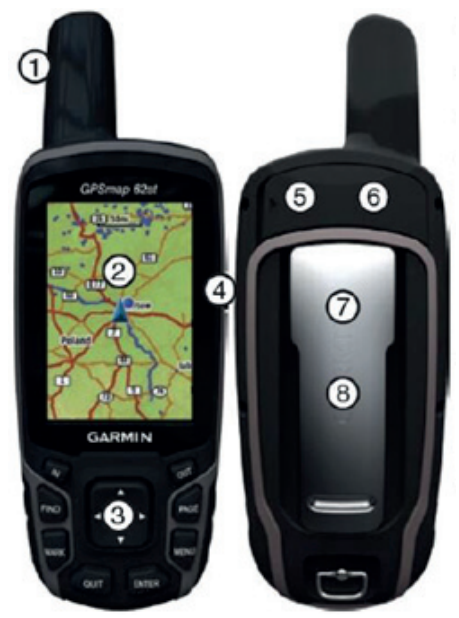

Fig. 1. Construction of the GPSmap62st receiver (GPSmap62 Series User's Guide): 1 - internal antenna, 2 - display, 3 - keypad, 4 - POWER key, 5 - mini-USB port, 6 - MMCX connector for external GPS antenna, 7 - microSD card slot, 8 - battery

Table 1 summarizes the technical specification and range of the Garmin GPSmap62st receiver functions. The parameters presented in Table 1 determined the choise of the receiver for the purposes of this study.

Table 1. Technical Specifications of the GPSmap62st receiver

\begin{tabular}{|c|c|}
\hline \multicolumn{2}{|c|}{ The physical properties and performance } \\
\hline The physical dimensions & $6.1 \times 16.0 \times 3.6 \mathrm{~cm}$ \\
\hline Display dimensions, width $\times$ height & $3.6 \times 5.5 \mathrm{~cm}$, diagonal $2.6 "(6.6 \mathrm{~cm})$ \\
\hline Display resolution, width $\times$ height & $160 \times 240$ pixels \\
\hline Display type & color (65 thous.), transflective-transparent TFT screen \\
\hline Mass & $260.1 \mathrm{~g}$ with batteries \\
\hline Battery & $\begin{array}{l}2 \text { AA batteries (sold separately), NiMH batteries or } \\
\text { lithium-ion recommended }\end{array}$ \\
\hline Battery life & 20 hours \\
\hline Waterproof class & IPX7 \\
\hline High-sensitivity receiver & YES \\
\hline Interface & compatibility with the rapid USB and NMEA 0183 \\
\hline Camera & NO \\
\hline
\end{tabular}


Table 1 cont.

\begin{tabular}{|l|c||}
\hline Barometric altimeter & YES \\
\hline Electronic compass & YES (tilt-compensated, 3-axial) \\
\hline \hline Transfer between devices & YES \\
\hline \hline \multicolumn{2}{|c||}{ Maps \& Memory } \\
\hline The base map & YES \\
\hline Preloaded maps & YES \\
\hline Ability to add maps & YES \\
\hline Built-in memory & 500 MB free memory \\
\hline Data Card Support & MES card (sold separately) \\
\hline Custom POIs & YES \\
\hline Waypoints / favorites / locations & 2000 \\
\hline Routes & 10 000 points, 200 saved routes \\
\hline Track log & YES \\
\hline \hline & Yieldwork (digital version) \\
\hline \hline Automatic routing & YES \\
\hline Geocaching & YES \\
\hline Compatibility with own maps & YES \\
\hline Hunting / fishing calendar & YES \\
\hline Information about the position of the sun \\
and moon & YES \\
\hline Tide tables & YES \\
\hline Measurement of surface area & \\
\hline Photo viewer & \\
\hline \hline
\end{tabular}

Source: www.garmin.com.pl

\subsection{Characteristics of the Study Area}

Two hand-held receivers Garmin GPSmap62st were used for the studies. It was assumed that their accuracy is identical. The measurement was performed by two persons who began measuring from the same point. One of them was moving around the perimeter of a plot of 1 ha, hereinafter referred to as plot 1 , while the other measured the land plot of 0.5 ha, hereinafter referred to as plot 2. (Fig. 2). The plots had one common side. Each plot was measured 15 times. The vertices of the measured plots were determined according to the intended project. After setting out all the points in the field, they were measured with the total station calculate the surface area of the used plot analytically from the obtained results. A sketch of the measuring base is shown in Figure 2. The coordinates obtained from these measurements are presented in the local coordinate system in Table 2. 


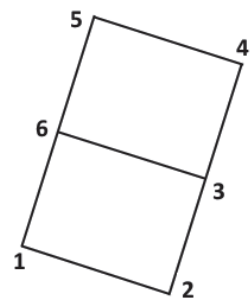

Fig. 2. The sketch of the measuring base

Table 2. The coordinates of the vertices of the test field in the local coordinate system

\begin{tabular}{|c|c|c|}
\hline Point number & $X$ coordinate & $Y$ coordinate \\
\hline \hline 1 & 1000.00 & 1000.00 \\
\hline 2 & 1000.00 & 1080.00 \\
\hline 3 & 1062.50 & 1080.00 \\
\hline 4 & 1124.99 & 1080.00 \\
\hline 5 & 1125.01 & 1000.00 \\
\hline 6 & 1062.49 & 1000.00 \\
\hline
\end{tabular}

Source: study based on tachometric measurements

The areas calculated on the basis of the above coordinates for the larger and smaller plots are respectively $10000 \mathrm{~m}^{2}$ and $5000 \mathrm{~m}^{2}$.

\section{Presentation of the Measurements Results}

To preview and present the research results BaseCamp software was used. This is free software from Garmin, for displaying maps, route planning, marking and editing points and traces and also the transfer of data between the receiver and computer. BaseCamp makes it easy to preview the shape of each of the traces, the amount of stored points, length of traveled route and the speed with which it was covered (Figs 6, 7). On the basis of this part of the analysis, it was found that the operation was performed without disruption of satellite system and all measurement cycles took place at the same pace with a similar number of points on traveled routes.

For each of the plots the obtained results were selected and the clear outliers rejected. Therefore the calculations have been made on the basis of 13 tracks recorded in the devices. These traces were the results of measurements of the surface areas of each measured plots, taken for further calculations. The measurements that have been analyzed are listed in the tables. Table 3 presents the results of measurements and partial calculations obtained for the bigger plot (plot 1). Similar calculations were made for the smaller plots (plot 2), But due to restrictions on the volume of text publications the authors did not present them as a whole. 


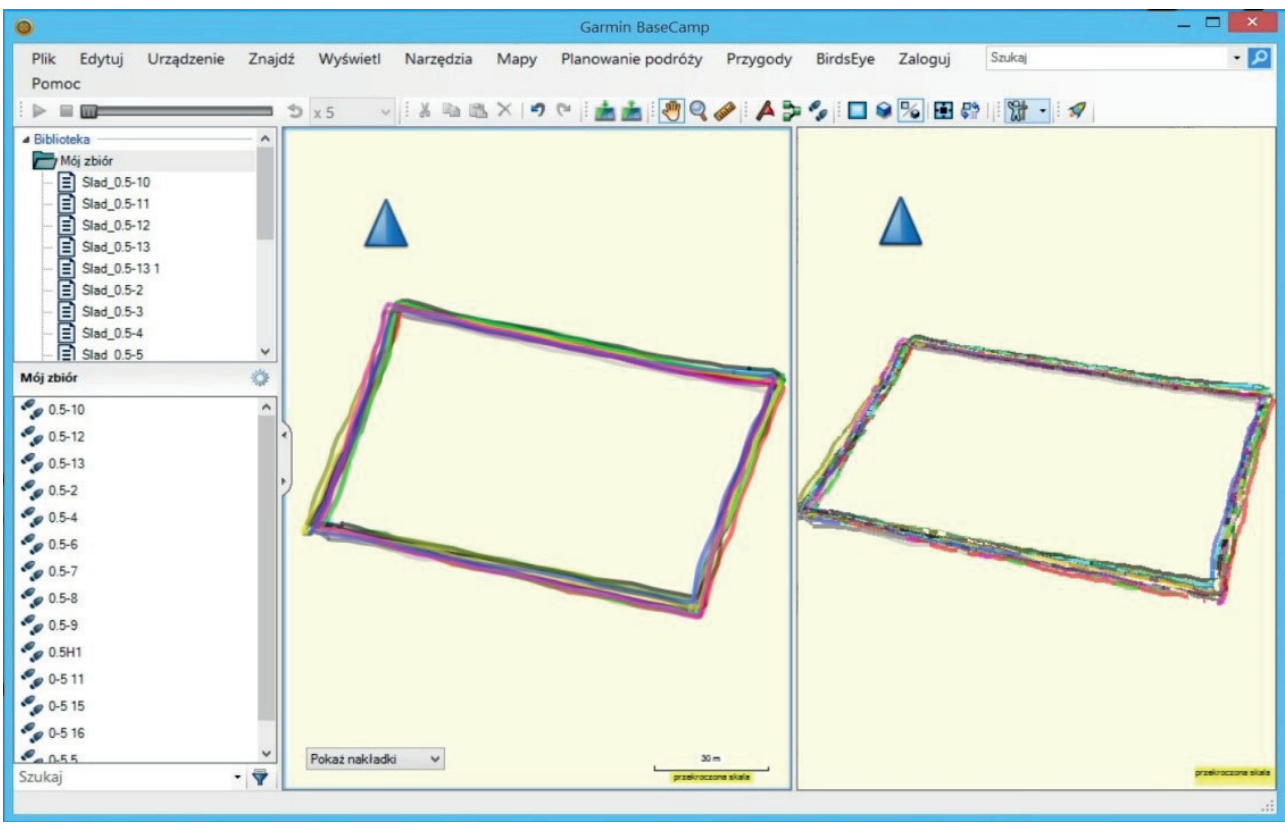

Fig. 6. View of saved tracks (the plots 1 and 2)

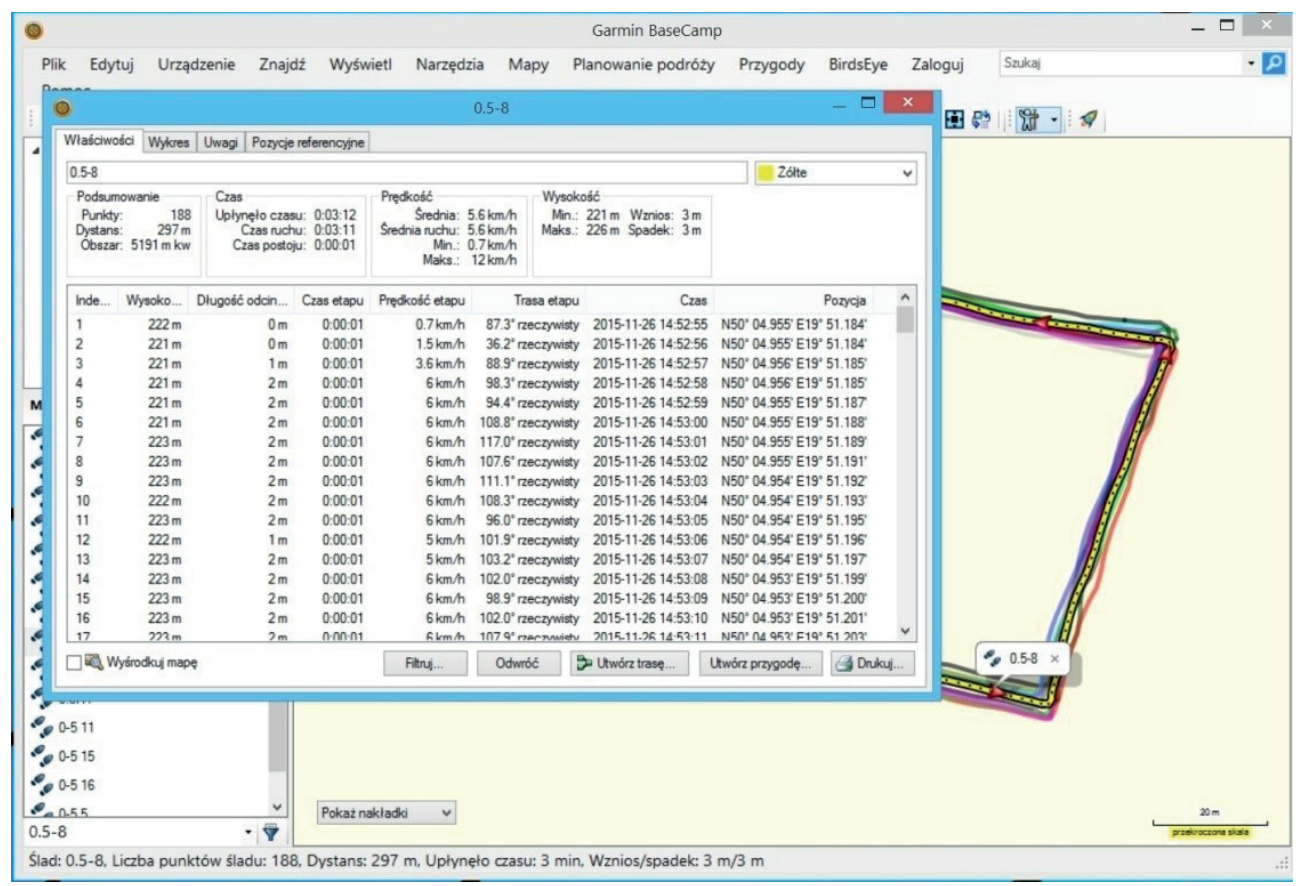

Fig. 7. The window of trace properties 
Table 3. The results of measurements of the surface area of the plot 1

\begin{tabular}{||c|c|c|c|c|c|c|c||}
\hline No. & $\begin{array}{c}\text { Number } \\
\text { of points }\end{array}$ & $\begin{array}{c}\text { Number of } \\
\text { point deviation } \\
\text { from the } \\
\text { average }\end{array}$ & $\begin{array}{c}\text { Distance } \\
{[\mathrm{m}]}\end{array}$ & $\begin{array}{c}\text { Distance } \\
\text { deviation } \\
\text { from the } \\
\text { average }\end{array}$ & Area [ha] & $\begin{array}{c}\text { Area } \\
\text { deviation } \\
\text { from the } \\
\text { average }\end{array}$ & [vv] \\
\hline \hline 1 & 314 & 36.1 & 430 & 13.15 & 1.0366 & 0.0281 & 0.0008 \\
\hline 2 & 314 & 36.1 & 419 & 2.15 & 1.0081 & -0.0004 & 0.0000 \\
\hline 3 & 300 & 22.1 & 416 & -0.85 & 1.0025 & -0.0060 & 0.0000 \\
\hline 4 & 294 & 16.1 & 416 & -0.85 & 0.9971 & -0.0114 & 0.0001 \\
\hline 5 & 295 & 17.1 & 417 & 0.15 & 1.0159 & 0.0074 & 0.0001 \\
\hline 6 & 300 & 22.1 & 422 & 5.15 & 1.0416 & 0.0331 & 0.0011 \\
\hline 7 & 273 & -4.9 & 415 & -1.85 & 1.0162 & 0.0077 & 0.0001 \\
\hline 8 & 300 & 22.1 & 410 & -6.85 & 0.9891 & -0.0194 & 0.0004 \\
\hline 9 & 261 & -16.9 & 409 & -7.85 & 0.9834 & -0.0251 & 0.0006 \\
\hline 10 & 249 & -28.9 & 413 & -3.85 & 0.9882 & -0.0203 & 0.0004 \\
\hline 11 & 281 & 3.1 & 417 & 0.15 & 1.007 & -0.0015 & 0.0000 \\
\hline 12 & 212 & -65.9 & 415 & -1.85 & 1.0026 & -0.0059 & 0.0000 \\
\hline 13 & 220 & -57.9 & 420 & 3.15 & 1.0219 & 0.0134 & 0.0002 \\
\hline Average & 277.9 & - & 416.85 & - & 1.0085 & - & - \\
\hline \hline
\end{tabular}

As shown in Table 3, the average measured surface area was 1.0085 ha. The minimum size is 0.9834 ha, while the maximum is equal to 1.0416 ha. The mean square error of the measured surface area was $170.98 \mathrm{~m}^{2}$, which represents $1.70 \%$ of the measured area. It has been calculated using the formula:

$$
m_{p}=\sqrt{\frac{[\mathrm{vv}]}{n-1}}
$$

After taking into account the accuracy of the receiver, the mean square error of the measured plot area, calculated from the formula (2) [9] was $24.83 \mathrm{~m}^{2}$ :

$$
m_{p}=2 m_{\text {point }}\left(1-\frac{1}{n}\right) \sqrt{P \frac{\pi}{n}}
$$

where:

$P$ - the average value of the surface area: $10085 \mathrm{~m}^{2}$,

$n$ - the median number of measuring points: 294,

$m_{\text {point }}$ - the mean square measurement error of the receiver under the given circumstances: $1.2 \mathrm{~m}$ (according to [9]) 
Calculated in this way error $24.83 \mathrm{~m}^{2}$ represents $0.25 \%$ of the average area of the plot. It is also nearly seven times smaller than the error without considering the accuracy of the receiver.

Similar statements and partial calculations were made referring to the tracks stored in the device for smaller plot (plot 2). Thus, in the case of a smaller plot the average size measured was 0.5082 ha. The minimum size is 0.4964 hectares, while the maximum 0.5191 ha. The mean square error for measured surface area was $92.47 \mathrm{~m}^{2}$, which represents $1.82 \%$ of the average measured surface area. On the other hand the mean square error of the measured plot, taking into account the accuracy of the receiver for a smaller plot is $22.0 \mathrm{~m}^{2}$ and represents $0.43 \%$ of the average area. The differences between the surface area calculated in the analytical process and the measured surface area are shown in Figures 8 and 9

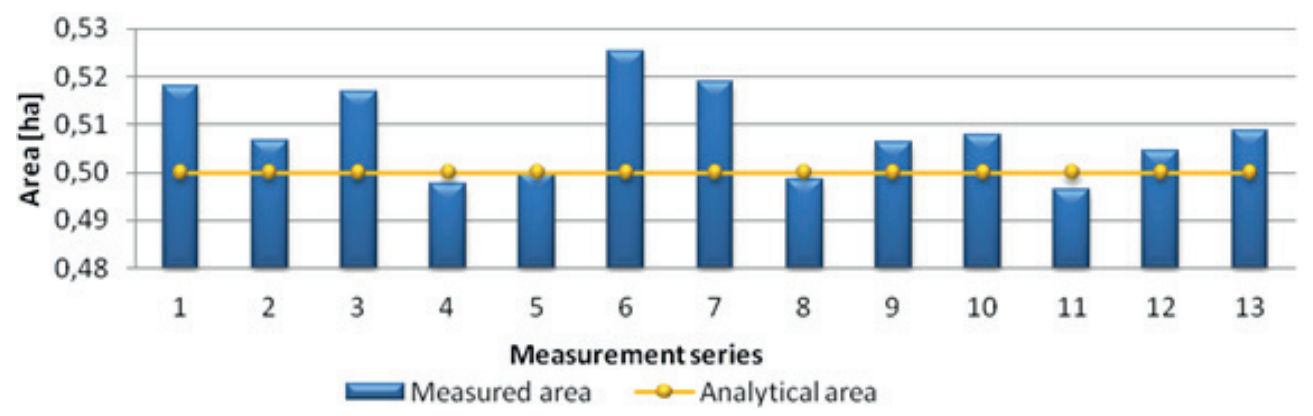

Fig. 8. Comparison of measured area with the analytical area -0.5 ha plot

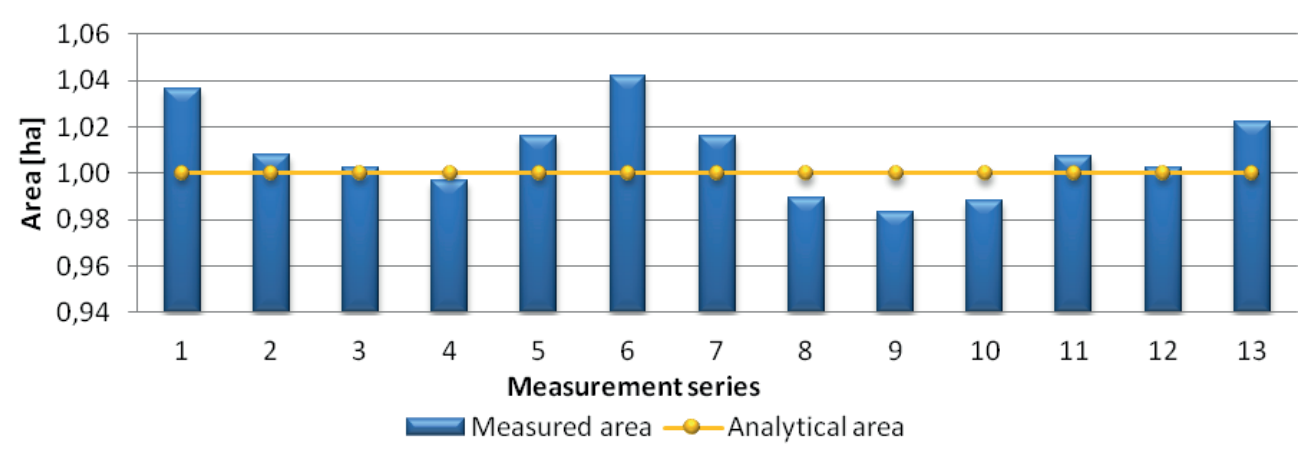

Fig. 9. Comparison of measured area with the analytical area -1 ha plot

Calculations showed the greatest deviation from the analytical value for the plot 1 amounting to $416 \mathrm{~m}^{2}$, while for the plot 2, it was $253 \mathrm{~m}^{2}$. The deviation of the average value from the analytical surface area amounted to plots 1 and 2 respectively $0.8 \%$ and $1.6 \%$. In both cases, about five series of measurements gave results very close to the analytical surface. 


\section{Conclusions}

The subject of the use of hand-held receivers in a variety of surveying tasks is for years the subject of considerations included among others in such references as $[3-5,7-9]$. Research has shown that the GPSmap62st is a handheld receiver exhibiting relatively high surface area measurement accuracy. When the recording interval is set in the receiver every 1 second, for 1 ha, about 300 measurement points were recorded. With regard to the earlier studies [3,4] - this number is several times higher than the measurement of very small plots of land (about 30 areas), using equipment from the same manufacturer - GPSMAP 76 which produces a much poorer result. In achieving considerable high accuracy of measurement undoubtedly helped the correction WAAS / EGNOS and the location of the measurement base in an open area. The results of this analysis confirmed earlier assumptions, that the size of the measured plot affects the measurement accuracy of its surface. For the larger plot (plot 1) the measurement mean square error is smaller. This means that as the plot area increases, the measurement of its surface area mean square error decreases. In addition, the obtained values of the mean square errors of the measured surface areas, taking into account the accuracy of the receiver are several times smaller than their counterparts in which this accuracy is not taken into account. These values for the two plots do not exceed 0.5\%. Handheld receiver Garmin GPSmap62st can be used in the surveying works of the lowest accuracies, such as measurement of the surface area to verify a planted area or location of the plot or guidance navigation in the terrain. Differences between the average surfaces measured and those calculated from coordinates, amounting for plot size of 1 hectare $0.8 \%$, while for the plot 0.5 ha $1.6 \%$ confirmed the previous researches [7-9].

\section{References}

[1] Deska K.: Analiza dokładności określenia powierzchni działek rolnych na potrzeby systemu IACS. Przegląd Geodezyjny, nr 1, 2006, pp. 3-9.

[2] Doskocz A.: Analiza dokładności obliczenia pola powierzchni ze wspótrzędnych. Przegląd Geodezyjny, nr 4, 2005, pp. 3-6.

[3] Kwinta A., Szeptalin A.: Wykorzystanie ręcznych odbiorników GNSS do pomiarów powierzchni działek rolnych. Infrastruktura i Ekologia Terenów Wiejskich, nr 6, 2010, pp. 157-166.

[4] Mika M.: Wykorzystanie ręcznych odbiorników GPS w Systemie Jednolitej Płatności Obszarowej dla wyznaczenia pól powierzchni działek. Infrastruktura i Ekologia Terenów Wiejskich, nr 3, 2011, pp. 53-62.

[5] Mika M.: Examination of the Capabilities of Some Models of Hand GPS Receivers for Purposes of Creation of Thematic Maps. Geomatics and Environmental Engineering, vol. 8, no. 2, 2014, pp. 47-56. 
[6] Mika M.: Geodezyjne, prawne i organizacyjne aspekty Jednolitego Systemu Płatności Obszarowej w Polsce. Geomatics and Environmental Engineering, vol. 1, no. 2, 2007, pp. 77-88.

[7] Mika M.: The use of hand-held GPS receivers for the identification of objects in a wooded area. Geomatics and Environmental Engineering, vol. 9, no. 1, 2015, pp. 75-82.

[8] Mika M., Salata T.: The use of local databases of spatial information for the preservation of spatial order on example of selected units of local government in Poland. [in:] 15th International Multidisciplinary Scientific Geoconference SGEM 2015, Informatics, Geomatics and Remote Sensing, Conference Proceedings Volume II, Cartography \& Gis, Bulgaria 2015, pp. 1163-1173, DOI: 10.5593/sgem2015B22.

[9] Plewako M.: Badanie dokładności ręcznych odbiorników GPS. Infrastruktura i Ekologia Terenów Wiejskich, nr 12, 2010, pp.103-107.

[10] www.garmin.com.pl. 